\title{
DETERMINASI ARSEN (As) dan MERKURI (Hg) DALAM AIR DAN SEDIMEN DI KOLAM BEKAS TAMBANG TIMAH (AIR KOLONG) DI PROPINSI BANGKA-BELITUNG, INDONESIA
}

\author{
Yanni Sudiyani' ${ }^{1)}$, Ardeniswan ${ }^{2)}$, dan Diana Rahayuningwulan ${ }^{3)}$ \\ (Diterima tanggal: 03-01-2011; Disetujui tanggal: 18-05-2011)
}

\begin{abstract}
ABSTRAK
Indonesia dikenal sebagai produsen timah terbesar kedua di dunia, di mana produksi timah sebagian besar berlokasi di Propinsi Bangka Belitung (Babel), yang termasuk dalam Sabuk Timah Asia Tenggara. Penambangan timah diperkirakan telah berdampak negatif pada lima belas sungai di Babel, sepuluh di antaranya berada di Pulau Bangka. Sebagian besar penduduk di Babel mengandalkan ketersediaan air bersih dari air sungai atau air kolong. Perusahaan Daerah Air Minum (PDAM) menggunakan beberapa kolam bekas penambangan (kolong) sebagai sumber air bakunya untuk diolah dan didistribusikan untuk kepentingan penduduk. Tujuan dari penelitian ini adalah menentukan konsentrasi logam berat arsen (As) dan merkuri (Hg) di dalam air dan sedimen dari beberapa kolong yang digunakan sebagai air baku PDAM. Pengambilan contoh uji dilakukan pada bulan kering dan bulan basah di 5(lima) lokasi dengan 15 titik sampling. Analisis meliputi parameter lapangan dan laboratorium, pengukuran logam Hg menggunakan cold vapor fumeless AAS Varian Spectro, AA 20plusVGA,1996; sedangkan logam As menggunakan AAS-VarianSpectro, AA-20 plus hydride, 1996 (SM 21st.,2005,APHA-AWWA-WEF, Part.No.3114). Hasil penentuan logam berat As dalam sedimen menunjukkan nilai konsentrasi di atas baku mutu sedimen WAC 173-204-320, terutama di Site I, yaitu di musim penghujan pada PDAM Pemali sebesar $84,84 \pm 0,36 \mathrm{mg} / \mathrm{L}$ serta di musim kemarau pada air baku PLN Merawang sebesar 99,686 $\pm 0,084 \mathrm{mg} / \mathrm{L}$ dan air baku PDAM Merawang sebesar 76,797 $\pm 3,685 \mathrm{mg} / \mathrm{L}$. Hasil penentuan logam berat $\mathrm{Hg}$ dalam sedimen menunjukkan nilai konsentrasi di atas baku mutu sedimen WAC 173-204-320, di Site I, yaitu di musim kemarau pada air baku PLN Merawang sebesar $0,679 \pm 0,001 \mathrm{mg} / \mathrm{L}$, air baku PDAM Pemali sebesar $0,513 \pm 0,153 \mathrm{mg} / \mathrm{L}$, Open Pit Pemali TB Timah $0,431 \pm 0,160$ $\mathrm{mg} / \mathrm{L}$, Kolong Kenanga $0,658 \pm 0,070 \mathrm{mg} / \mathrm{L}$, Site III Kolong Bikang 0,611 $\pm 0,031 \mathrm{mg} / \mathrm{L}$, Kolong Acam Rindik $0,444 \pm 0,077 \mathrm{mg} / \mathrm{L}$. Konsentrasi As dalam air memenuhi baku mutu air baku air minum Peraturan Pemerintah no. 82 tahun 2001, sedangkan Hg melebihi bakumutu..
\end{abstract}

Kata kunci: air bersih, Bangka Belitung, kolong, logam berat, dan sedimen.

\begin{abstract}
Indonesia is known as the second largest tin producer in the world and most of tin productions placed in BangkaBelitung(Babel) Province which located in the South-East Asia Tin Belt. Tin mining is estimated negatively impacted to 15 rivers in Babel, ten of which are in Bangka. Most of residents depend on those rivers or ex-tin mining pit as their water sources. The municipal water supply (PDAM) is using some old-pits as their Air baku sources to be treated and distributed for local residents. Objectives of this study were to determine arsenic(As) and mercury ( Hg) elements in water and sediment from several ex-tin mine pits (kolong) that usually used as water sources for PDAM. Sampling was done in wet and dry season at five sites area covered 15 sampling locations. Analysis of Hg using cold vapor fumeless AAS Varian-Spectro, AA-20plus VGA,1996 whereas As using AAS Varian-Spectro, AA-20plus hydride, 1996 (SM 21st.,2005, APHA-AWWA-WEF, Part. No.3114). The results obtained in this investigation shows that As and Hg in sediment were exceed sediment quality standard WAC 173-204-320, for mostly found in Site I. Arsenic concentration in water was below limit value for raw water for drinking water quality standard Government Regulation no 82/2001, but mercury was exceeded.
\end{abstract}

Keywords: clean water, Bangka Belitung, ex-tin mine pit, heavy metals, and sediment.

\footnotetext{
1) Pusat Penelitian Kimia Lembaga Ilmu Pengetahuan Indonesia, Kawasan Puspiptek Serpong, Tangerang, Telp.: 021-7560090 Fax.: 021-7560549.

2,3)Kampus LIPI, Jalan Cisitu, Bandung, Telp. : 022 - 2503051 Fax.: 022-2507772. Email: 1)sudiyani@gmail.com, 2)gutjis@yahoo.com, ${ }^{3)}$ d_wulan@yahoo.com.
} 


\section{PENDAHULUAN}

Indonesia dikenal sebagai produsen timah terbesar kedua di dunia dan produksi timah sebagian besar berlokasi di Propinsi Bangka Belitung (Babel), yang termasuk dalam South East Asia Tin Belt. Propinsi Bangka Belitung beriklim tropis dengan musim kemarau antara bulan Mei dan Oktober serta musim penghujan antara November danApril.

Penambangan timah di Propinsi Babel dilakukan oleh perusahaan penambang timah dan penambang rakyat. Banyaknya jumlah kolong yang tidak dikelola memicu terjadi kerusakan lingkungan penduduk di Babel mengkhawatirkan ketersediaan air bersih akan semakin sulit diperoleh. Suplai air bersih untuk PDAM dikhawatirkan akan terkontaminasi, karena air kolong merupakan sumber air potensial untuk penduduk setempat, terutama di musim kemarau. Hal ini menyebabkan masalah kesehatan, penduduk menggunakan air kolong sebagai sumber air untuk keperluan mandi, cuci dan toilet. Terkadang air kolong digunakan sebagai air baku air minum ataupun digunakan sebagai tambak ikan (fishfarming).

Aktivitas penambangan mineral berdampak pada tereksposnya logamlogam sedimen ke permukaan atau bahkan memasuki lingkungan perairan. Logam berat berada di lingkungan sebagai hasil dari proses alam maupun pencemar dari aktivitas manusia ${ }^{1)}$.
Logam berat bersifat stabil dan merupakan pencemar lingkungan yang persisten terhadap lingkungan perairan. Pendekatan kimiawi, toksikologi dan ekologi telah dipelajari untuk menilai dampak pencemaran logam berat di perairan.

Di beberapa kolong, $\mathrm{pH}$ air berkisar antara 4,5 - 8,4, dan mungkin mengandung logam berat seperti arsen, mangan, timbal, kadmium, seng, tembaga, dll. Keberadaan arsen di permukaan merupakan proses alamiah di lokasi penambangan mineral, dimana dapat menimbulkan kontaminasi yang cukup signifikan terhadap kualitas air, baik air permukaan maupun air tanah ${ }^{2)}$. Gejala kronis toksisitas As antara lain kerusakan sistem syaraf, blackfoot disease (jaringan rusak), hiper pigmentasi kulit, keratosis, karsinoma kulit, dan kanker gastrointestinal, ${ }^{2)}$ - Logam merkuri, dalam limbah berbentuk merkuri sulfat (sangat beracun), memiliki kemungkinan toksisitas akibat terabsorbsi melalui pernafasan (bentuk uap) maupun kontak kulit dengan gejala akut berupa korosif terhadap kulit dan jaringan lunak (larutan), diare, kerusakan ginjal, kematian dalam 10 hari, sedangkan akibat kronik berupa kerusakan ginjal, gigi, tremor otot, depresi ${ }^{3)}$.

Tujuan dari penelitian ini adalah menentukan konsentrasi logam berat As dan $\mathrm{Hg}$ dalam air dan sedimen dari beberapa kolong yang digunakan sebagai air baku untuk air minum, 
tambak ikan, dan beberapa kolong yang masih berfungsi sebagai area penambangan. Data tersebut dapat menginformasikan konsentrasi logam berat di kolong lokasi sampling sehingga membantu pemerintah daerah setempat dalam mengetahui kualitas lokasi kolong sebagai sumber air baku air minum.

\section{LOKASI PENENTUAN PENGAMBILAN CONTOH UJI (SAMPLING)}

Sampling dilakukan di beberapa kolong di Pulau Bangka jumlah kolongnya paling banyak dibandingkan dengan kolong di Pulau Belitung, dengan kriteria kolong tua ( $>40$ tahun), kolong muda ( $\geq 25$ tahun), dan kolong tambang aktif. Waktu adalah di penghujung musim penghujan, bulan April 2009 dan musim kemarau di bulan Agustus 2009. Lokasi sampling ditentukan pada kolong yang mewakili setiap area di masing-masing kabupaten di Pulau Bangka, sehingga diperoleh 15 (lima belas) titik sampling pada lima area. Kolong tersebut tergolong kolong tua yang berusia $>40$ tahun dan kolong muda yang berusia $\geq 25$ tahun. Lokasi sampling disajikan dalam Tabel1 dan Gambar 1.

Tabel 1. Kondisi lokasi sampling .

\begin{tabular}{|c|c|c|c|}
\hline \multirow{2}{*}{ Area } & \multirow{2}{*}{ No. } & Lokasi Sampling & \multirow{2}{*}{ Koordinat } \\
\hline & & Musim Penghujan (Wet Season) & \\
\hline \multirow{4}{*}{ Site I } & 1 & Air Baku PDAM Pemali, Sungai Liat & 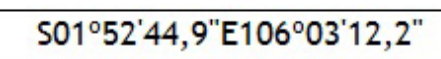 \\
\hline & 2 & PT Timah Mapur - Belinyu Utara & S01 $40^{\circ} 46,3^{\prime \prime}$ E10559'59,3" \\
\hline & 3 & Air Baku PDAM Belinyu & S01ํㄷ' $44,9^{\prime \prime E} 106^{\circ} 03^{\prime} 12,2^{\prime \prime}$ \\
\hline & 4. & TB Riding Panjang & S01'59'10,0" E106ㅇ' $42,5^{\prime \prime}$ \\
\hline Site II & 5. & Air Baku PDAM Bacang -Pangkal Pinang & S02 $07^{\circ} 27,3^{\prime \prime E} 106^{\circ} 08^{\prime} 38,2^{\prime \prime}$ \\
\hline Site IV & 6. & Fish Farming Koba & $\mathrm{SO}^{\circ} 32^{\prime} 17,1^{\prime \prime E} 106^{\circ} 23^{\prime} 57,5^{\prime \prime}$ \\
\hline \multirow[t]{2}{*}{ Site V } & 7. & PDAM Muntok & 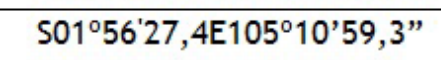 \\
\hline & & Musim Kemarau (Dry Season) & \\
\hline \multirow{6}{*}{ Site I } & 8. & Air Baku PLN Merawang & S01 ${ }^{\circ} 57^{\prime} 15,3^{\prime \prime} \mathrm{E} 106^{\circ} 06^{\prime} 43,1^{\prime \prime}$ \\
\hline & & PDAM Tirta Bangka -Merawang & S01 ${ }^{\circ} 57^{\prime} 14,4^{\prime \prime} \mathrm{E} 106^{\circ} 06^{\prime} 60,5^{\prime \prime}$ \\
\hline & 9. & PDAM Tirta Bangka - Pemali & S0151'44,7" E10604'11" \\
\hline & & Open pit Pemali TB Timah & $S 01^{\circ} 52^{\prime} 58,6^{\prime \prime} \mathrm{E} 106^{\circ} 02^{\prime} 43,1^{\prime \prime}$ \\
\hline & 10 & Air Jangkang Ex TB 1.9 - Bangka Induk & 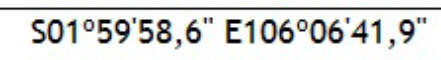 \\
\hline & 11 & Kolong Kenanga & S015'ㄴ' $27,4^{\prime \prime}$ E10606’55" \\
\hline \multirow{2}{*}{ Site II } & 12 & K. Retensi Kacang Pedang Hilir I & S020. $08^{\prime} 00^{\prime E} 106^{\circ} 05^{\prime} 70^{\prime \prime}$ \\
\hline & & K. Retensi Kacang Pedang Hilir II & 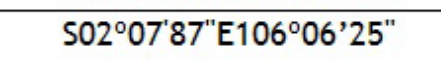 \\
\hline \multirow{3}{*}{ Site III } & 13. & Kolong Bikang Toboali & $\mathrm{SO}^{\circ} 55^{\prime} 54,5^{\prime \prime} \mathrm{E} 106^{\circ} 27^{\prime} 48,7^{\prime \prime}$ \\
\hline & 14. & Kolong Parit TigaToboali & $503^{\circ} 00^{\prime} 06,2^{\prime \prime} \mathrm{E} 106^{\circ} 32^{\prime} 42,4^{\prime \prime}$ \\
\hline & 15. & Kolong Acam Rindik - Selatan & 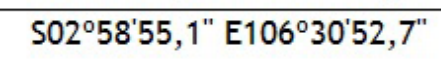 \\
\hline
\end{tabular}




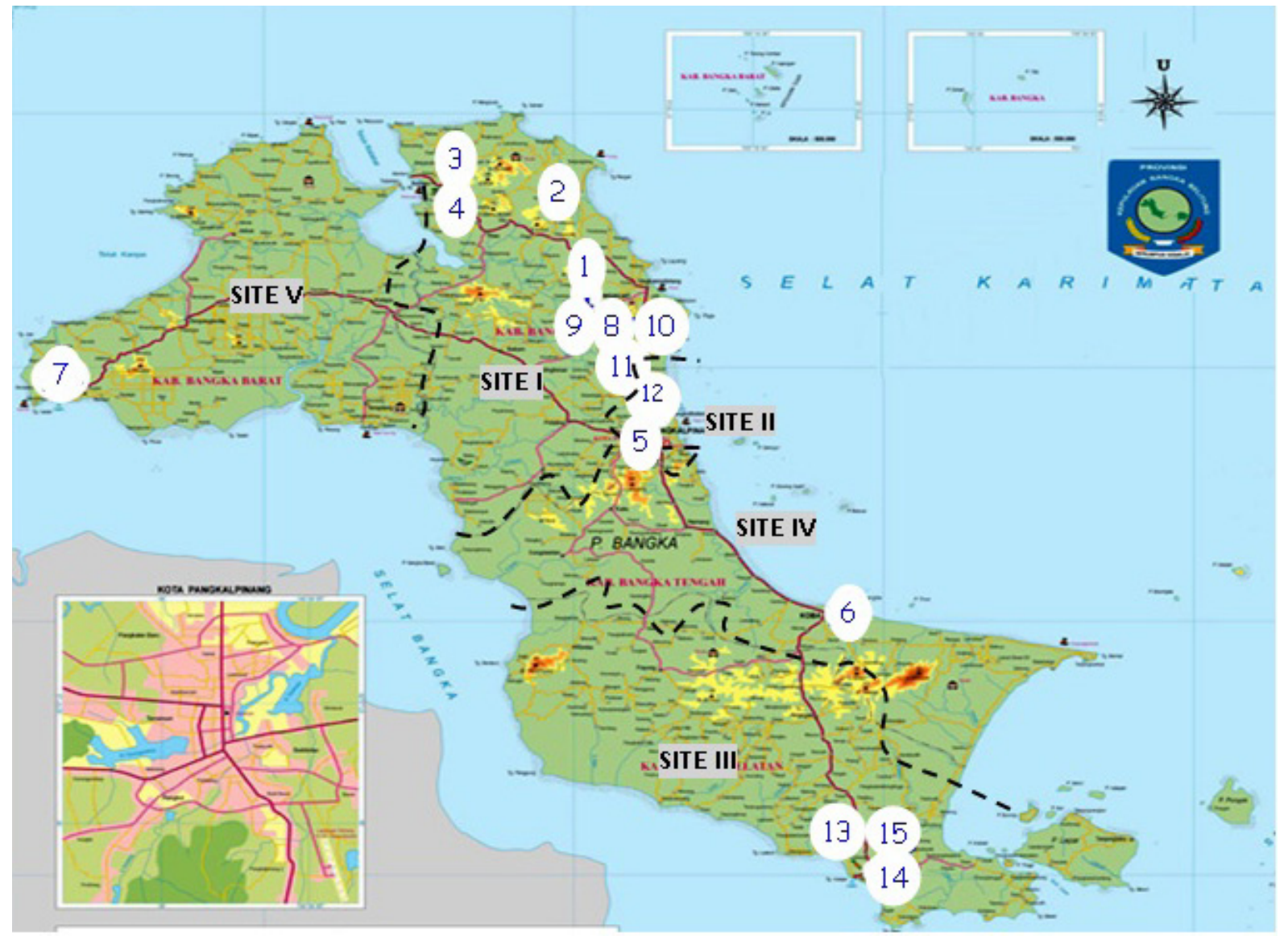

Gambar 1. Peta Bangka Belitung (Babel) menunjukkan lokasi sampling.

\section{METODA}

Sampling air dilakukan menggunakan horizontal water sampler dengan volume dua liter, menggunakan metoda komposit sampling berdasarkan kedalaman, di mana dilakukan pencampuran sampel air di tiap lokasi dari beberapa titik kedalaman (h). Titik sampling ditentukan berdasarkan kedalaman $0,2 \mathrm{x}$ h dan $0,8 \mathrm{x} \mathrm{h}$.

Pengukuran parameter kimia fisik di lokasi sampling dilakukan menggunakan Water Quality Checker Horiba. Hal ini dilakukan untuk menghindari perubahan konsentrasi parameter lapangan yang akan diukur, seperti DO (dissolved oxygen) dan $\mathrm{pH}$ yang nilainya mudah berubah terhadap waktu. Sampel air dari setiap lokasi sampling dimasukkan ke dalam botol poly ethylene satu liter, di asamkan dengan asam nitrat p.a hingga pH 2 kemudian dibawa ke laboratorium untuk dianalisa (International Standard, ISO 5667-2:1991(E)).

Sampling sedimen dilakukan menggunakan Eyckman Grab sampler. Sampel sedimen dari setiap lokasi sampling dimasukkan ke dalam wadah polyethylene 1 liter, diletakkan di dalam cooler box untuk kemudian dianalisa di laboratorium ${ }^{4)}$.

Setiap sampel air dihomogenisasi dan di saring menggunakan kertas saring Whatman no. 41. Filtrat yang 
terkumpul selanjutnya akan dianalisis. Sedangkan seluruh sampel sedimen dikeringkan menggunakan oven pada suhu $60^{\circ} \mathrm{C}$ selama $2 \times 8$ jam untuk menghilangkan kadar air. Pengeringan dilakukan hingga penimbangan sampel menunjukkan tidak terjadinya penurunan berat signifikan. Sedimen kering kemudian diayak menggunakan 200 mesh-sieve, dimasukkan ke dalam Erlenmeyer untuk kemudian di-digest dengan aqua regia, yaitu campuran larutan asam hidroklorida-asam nitrat (1:2). Hasil digesti selanjutnya akan dianalisis. Setiap sampel dianalisis sebanyak tiga ulangan, dengan larutan standar yang dipersiapkan dari larutan stok.

Sampel air dan sedimen dianalisis kadar logam berat $\mathrm{Hg}$ menggunakan cold vapor fumeless Atomic Absorbtion Spectrofotometer (AAS), Varian Spectro, AA 20 plusVGA, 1996.
Sedangkan As menggunakan AAS Varian Spectro, AA 20 plus hydride, $1996^{5)}$.

Konsentrasi logam berat ditunjukkan dalam satuan milligram per liter (mg/l) untuk sampel air dan milligram per kilogram $(\mathrm{mg} / \mathrm{kg})$ berat kering untuk sedimen.

Hasil analisis ditampilkan dalam "nilai rata-rata \pm standar deviasi", kemudian dibandingkan dengan baku mutu. Air baku PDAM atau air kolong dibandingkan dengan baku mutu PP No. 82 tahun 2001 Kelas I untuk air baku air minum. Hasil analisis sedimen dibandingkan dengan baku mutu SedimenWAC 173-204-320 6)

\section{HASIL DAN PEMBAHASAN}

Parameter kimia fisik sampel air di setiap lokasi sampling diukur in-situ di lokasi sampling dengan hasil seperti dicantumkan dalam Tabel 2. 
Tabel 2. Parameter Kimia-fisik diukur di lokasi sampling

\begin{tabular}{|c|c|c|c|c|c|c|c|}
\hline \multirow{2}{*}{$\begin{array}{c}\text { No. } \\
\text { Lokasi }\end{array}$} & Lokasi Sampling & Kegunaan & $\mathrm{pH}$ & $\begin{array}{c}\text { Konduktiviti } \\
\left({ }^{\circ} \mathrm{S} / \mathrm{cm}\right)\end{array}$ & $\begin{array}{c}\mathrm{DO} \\
(\mathrm{mg} / \mathrm{L})\end{array}$ & $\begin{array}{l}\text { Temp. } \\
\left({ }^{\circ} \mathrm{C}\right)\end{array}$ & $\begin{array}{c}\text { Salinitas } \\
(\%)\end{array}$ \\
\hline & \multicolumn{7}{|c|}{ Musim Penghujan } \\
\hline 1 & PDAM Pemali & Air baku & 7,46 & 0,14 & 0,95 & 31,4 & 0,0 \\
\hline 2 & TB PT Timah Mapur & Tambang Aktif & 3,6 & 2,51 & 0,87 & 29,6 & 0,12 \\
\hline 3 & PDAM Belinyu & Air baku & 4,67 & 0,046 & 0,83 & 30,4 & 0,0 \\
\hline 4 & TB Riding Panjang & Tambang Aktif & 5,62 & 0,038 & 0,76 & 28,9 & 0,0 \\
\hline 5 & PDAM Bacang & Air baku & 8,45 & 0,047 & 0,96 & 30,8 & 0,0 \\
\hline 6 & Fish Farm Koba & Tambak & 7,43 & 0,076 & 1,07 & 32,5 & 0,0 \\
\hline \multirow[t]{2}{*}{7} & PDAM Muntok & Air baku & & & & & \\
\hline & \multicolumn{7}{|c|}{ Musim Kemarau } \\
\hline \multirow[t]{2}{*}{8} & Air Baku PLN Merawang & Air baku PLN & 6,84 & 0,048 & 0,94 & 32,9 & 0,0 \\
\hline & PDAM Tirta Bangka -Merawang & Air baku & 6,95 & 0,012 & 0,96 & 31,3 & 0,0 \\
\hline \multirow[t]{2}{*}{9} & PDAM - Pemali & Air baku & 7,10 & 0,012 & 0,88 & 30,6 & 0,0 \\
\hline & Openpit Pemali TB Timah & Tambang Aktif & 4,83 & 0,040 & 1,04 & 30,9 & 0,0 \\
\hline 10 & Air Jangkang Ex TB 1.9 & Air baku & 3,07 & 5,5 & 0,97 & 31,2 & 0,29 \\
\hline 11 & Kolong Kenanga & Air baku & 7,09 & 0,020 & 1,04 & 33,1 & 0,0 \\
\hline \multirow[t]{2}{*}{12} & K. Ret.Kacang Pedang Hilir I & Air baku & 6,65 & 2,94 & 0,92 & 31,3 & 0,14 \\
\hline & K. Ret. Kacang Pedang Hilir II & Air baku & 6,65 & 2,94 & 0,92 & 31,3 & 0,14 \\
\hline 13 & Kolong Bikang Toboali & Air baku & 4,73 & 0,096 & 0,86 & 29,7 & 0,0 \\
\hline 14 & Kolong Parit Tiga Toboali & Air baku & 6,21 & 0,026 & 0,98 & 30,7 & 0,0 \\
\hline 15 & Kolong Acam Rindik & Air baku & 6,04 & 0,027 & 0,84 & 28,6 & 0,0 \\
\hline
\end{tabular}

Berdasarkan hasil analisis di lapangan terhadap parameter kimia dan fisika, diperoleh bahwa nilai $\mathrm{pH}$ berkisar: 3,07 - 8,4. Nilai $\mathrm{pH}$ air pada kolong tua berada pada $\mathrm{pH}$ netral, sedangkan pH pada kolong muda berada pada $\mathrm{pH}$ asam. Pengukuran parameter terhadap air tambang aktif menunjukkan $\mathrm{pH}$ asam 3,6-5,62. Kolong tua seperti Open Pit Pemali yang sedang dilakukan pengerukan untuk memperdalam area penambangan memiliki nilai $\mathrm{pH}$ asam .

Pengukuran terhadap parameter DO untuk lokasi kolong tua dan muda berkisar pada 0,83-1,04 mg/L. Bila nilai DO pada air baku PDAM dibandingkan dengan baku mutu PP no. 82 tahun 2001 , maka nilai DO di lokasi sampling tidak memenuhi kriteria kelas I dan hanya memenuhi kriteria kelas IV dengan peruntukan sebagai sumber pengairan tanaman atau sejenisnya. Nilai oksigen terlarut merepresentasikan nilai ketersediaan oksigen yang terlarut di kolongl okasi sampling, hal ini merupakan kebutuhan pokok bagi kehidupan ekosistem perairan kolong.

Rendahnya nilai DO di lokasi sampling dimungkinkan dari banyaknya jumlah ganggang di lokasi sampling. Selain itu, tingginya temperatur air di lokasi sampling juga mempengaruhi nilai DO. Kelarutan oksigen pada air permukaan tidak tercemar berkisar $15 \mathrm{mg} / \mathrm{L}$ pada $0^{\circ} \mathrm{C}$ dan menjadi $7 \mathrm{mg} / \mathrm{L}$ pada $35^{\circ} \mathrm{C}$ pada 
satu atmosfer ${ }^{7}$. Di musim penghujan, temperatur di lokasi sampling dapat mencapai $32,5^{\circ} \mathrm{C}$, sedangkan di musim kemarau dapat mencapai $33,1^{\circ} \mathrm{C}$.

Hasil analisis sampel air di musim penghujan dari beberapa lokasi sampling disajikan dalam Tabel 3, sedangkan analisis terhadap sedimen dicantumkan dalam Tabel 4.
Beberapa nilai konsentrasi logam yang ditampilkan dalam Tabel 3 dan Tabel 4 menunjukkan nilai sebanding dengan Method Detection Limit (MDL), dimana merupakan batas kemampuan metoda yang digunakan untuk mendeteksi konsentrasi sampel uji. Nilai tersebut yang digunakan untuk menyatakan hasil deteksi sampel, mengingat pemilihan metoda mempunyai deteksi lebih kecil dari baku mutu yang akan diacu.

Tabel 3. Deteksi logam berat dalam air di lokasi sampling musim penghujan

\begin{tabular}{|c|c|c|c|c|}
\hline \multirow{2}{*}{ Area } & Titik Sampling & \multirow{2}{*}{ Satuan } & \multicolumn{2}{|c|}{ Konsentrasi Logam Berat dalam Air (mg//L) } \\
\cline { 4 - 5 } & & & As & Hg \\
\hline \multirow{3}{*}{ Site I } & Air Baku PDAM Pemali & $\mathrm{mg} / \mathrm{L}$ & $0,0065 \pm 0,0007$ & 0,001 \\
\cline { 2 - 5 } & TB PT Timah Mapur & $\mathrm{mg} / \mathrm{L}$ & 0,003 & 0,001 \\
\cline { 2 - 5 } & Air Baku PDAM Belinyu & $\mathrm{mg} / \mathrm{L}$ & 0,003 & 0,001 \\
\cline { 2 - 5 } & Air Baku TB Riding Panjang & $\mathrm{mg} / \mathrm{L}$ & 0,003 & 0,001 \\
\hline \multirow{2}{*}{ Site II } & Air Baku PDAM Bacang & $\mathrm{mg} / \mathrm{L}$ & 0,003 & 0,001 \\
\hline Site IV & Air Baku PDAM Koba & $\mathrm{mg} / \mathrm{L}$ & 0,003 & 0,001 \\
\hline Site V & Air Baku PDAM Muntok & $\mathrm{mg} / \mathrm{L}$ & 0,003 & 0,001 \\
\hline \multicolumn{2}{|c|}{ MDL(Method Detection Limit) } & $\mathrm{mg} / \mathrm{L}$ & 0,003 & 0,001 \\
\hline \multicolumn{2}{|c|}{ PP RI no 82 tahun 2001 kelas I } & $\mathrm{mg} / \mathrm{L}$ & 0,05 & 0.001 \\
\hline
\end{tabular}

Tabel 4. Deteksi logam berat dalam sedimen di lokasi sampling musim penghujan

\begin{tabular}{|c|c|c|c|c|}
\hline \multirow{2}{*}{ Area } & Titik Sampling & \multirow{2}{*}{ Satuan } & \multicolumn{2}{|c|}{$\begin{array}{c}\text { Konsentrasi Logam Berat dalam Sedimen } \\
\text { (mg/kg Berat Kering)* }\end{array}$} \\
\cline { 3 - 5 } & & & As & Hg \\
\hline \multirow{3}{*}{ Site I } & PDAM Pemali & $\mathrm{mg} / \mathrm{L}$ & $84,84 \pm 0,36$ & $0,04 \pm 0,00$ \\
\cline { 2 - 5 } & PT TimahMapur & $\mathrm{mg} / \mathrm{L}$ & $0,47 \pm 0,04$ & $0,00 \pm 0,00$ \\
\cline { 2 - 5 } & PDAM Belinyu & $\mathrm{mg} / \mathrm{L}$ & $9,85 \pm 0,14$ & $0,25 \pm 0,02$ \\
\cline { 2 - 5 } & TB Riding Panjang & $\mathrm{mg} / \mathrm{L}$ & $12,09 \pm 0,74$ & $0,18 \pm 0,00$ \\
\hline \multirow{2}{*}{ Site II } & PDAM Bacang & $\mathrm{mg} / \mathrm{L}$ & $4,26 \pm 0,75$ & $0,04 \pm 0,00$ \\
\hline Site IV & FishfarmKoba & $\mathrm{mg} / \mathrm{L}$ & $7,76 \pm 0,95$ & $0,06 \pm 0,02$ \\
\hline Site V & Muntok & $\mathrm{mg} / \mathrm{L}$ & 0,003 & 0,001 \\
\hline \multicolumn{2}{|c|}{ MDL (Method Detection Limit) } & $\mathrm{mg} / \mathrm{L}$ & 0,003 & 0,001 \\
\hline \multicolumn{2}{|c|}{ Baku MutuSedimen WAC 173-204-320 } & $\mathrm{mg} / \mathrm{L}$ & 57 & 0,41 \\
\hline
\end{tabular}

*lihat Tabel 1. Tiap sampel dianalisis sebanyak tiga ulangan (triplo). 
Berdasarkan analisis konsentrasi logam berat dalam Tabel 3, konsentrasi logam berat dalam air baku PDAM tergolong rendah dan masih memenuhi baku mutu PP No. 82 tahun 2001 Kelas I. Sedangkan konsentrasi logam berat dalam sedimen pada Tabel 4, menunjukkan adanya nilai As yang melebihi baku mutu sedimen WAC 173-204-320 yaitu di Site I (PDAM Pemali). Faktor ekologi seperti DO, salinitas memiliki efek yang signifikan terhadap desorpsi (sedimen ke air) dan bioakumulasi logam ${ }^{1)}$. Bila dibandingkan konsentrasi logam arsen dalam sedimen juga sebanding dengan tingginya konsentrasi As dalam air, sebagaimana ditunjukkan dalam gambar 2. Hal ini disebabkan oleh kelarutan As yang tergantung pada nilai $\mathrm{pH}$ air. Semakin tinggi nilai $\mathrm{pH}$ air (semakin basa) maka As dalam air akan semakin tinggi, seperti tercantum dalam gambar 3 .

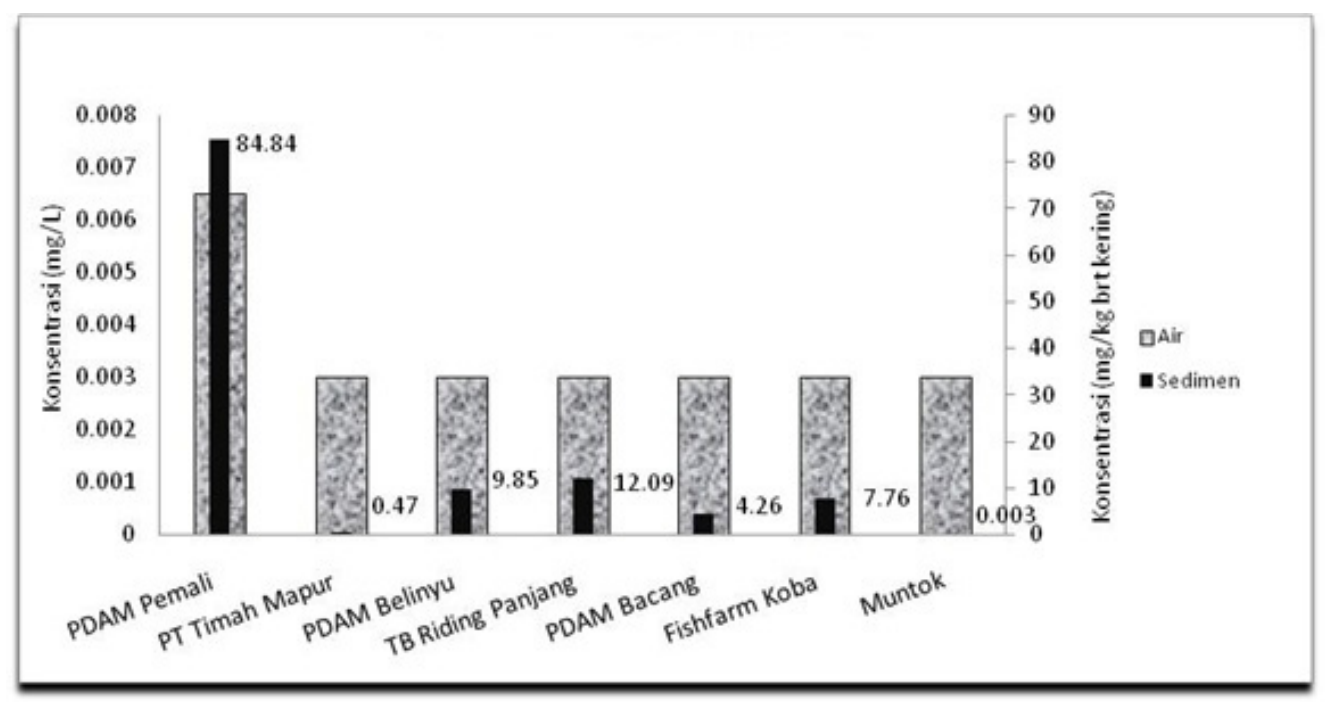

Gambar 2.Konsentrasi Logam As di Beberapa Lokasi Sampling Musim Penghujan.

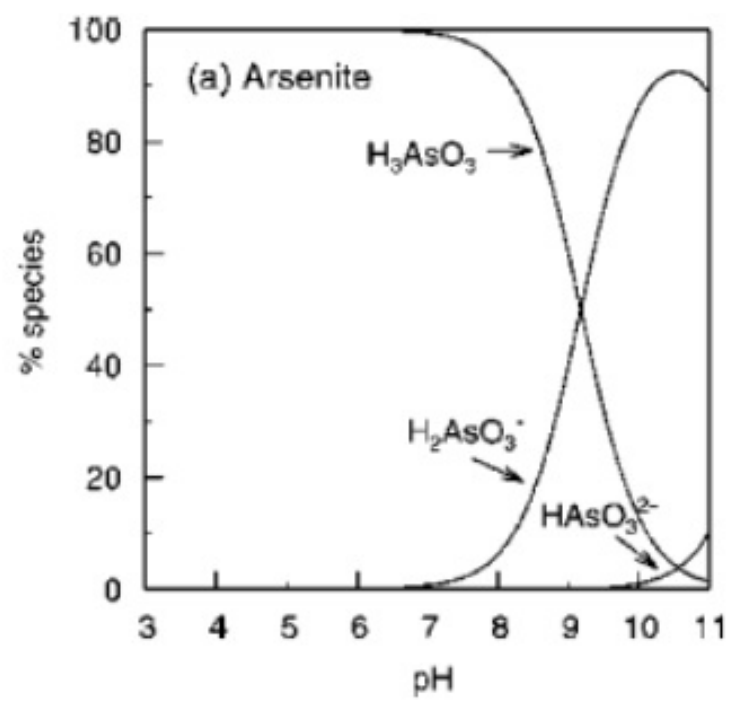

Gambar 3. Spesiasi Arsenite, As (III), sebagai fungsi $\mathrm{pH}^{8)}$. 


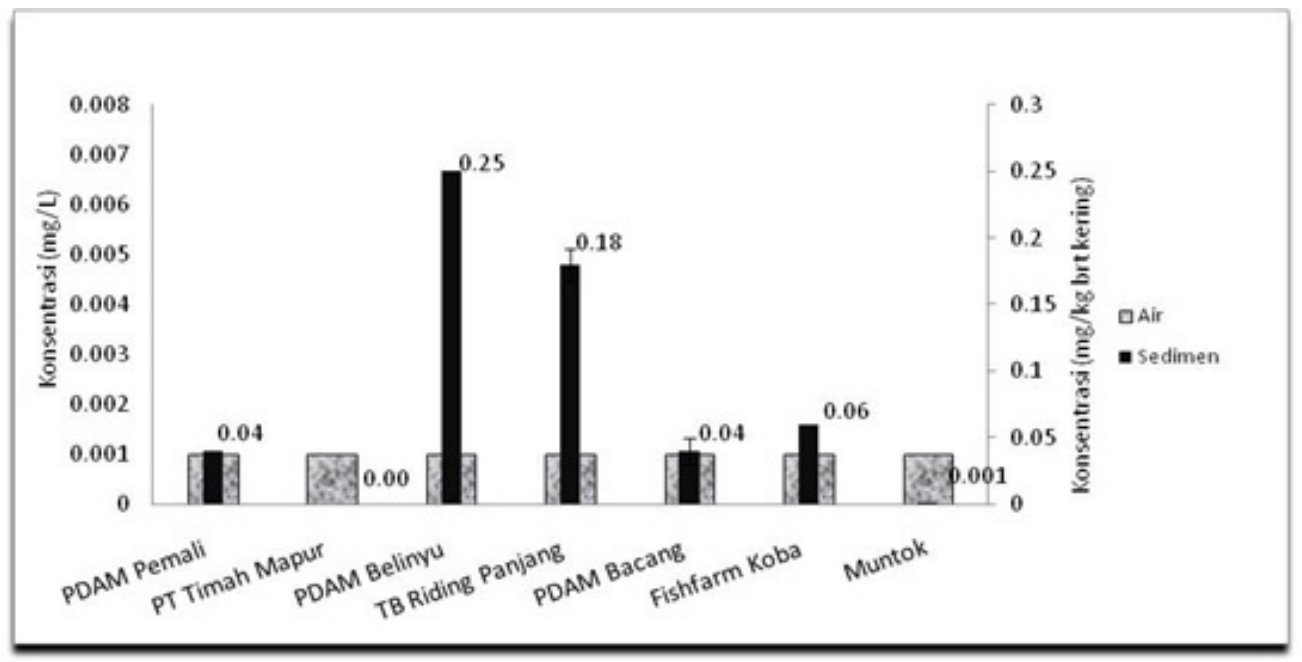

Gambar 4. Konsentrasi Hg di Beberapa Lokasi Sampling Musim Penghujan.

Umumnya konsentrasi logam berat dalam air di musim kemarau lebih tinggi dibandingkan musim penghujan, sebagaimana terlihat dalam Tabel 5. Hasil analisa logam berat dalam air menunjukkan nilai di bawah baku mutu untuk As, sedangkan $\mathrm{Hg}$ di beberapa lokasi sampling berada di atas bakumutu PP No 82 tahun 2001. Namun lokasi sampling yang menunjukkan konsentrasi merkuri di atas baku mutu tidak dipergunakan sebagai air baku PDAM, melainkan sebagai air baku PLN dan sumber air masyarakat (Kolong Kenanga dan Kolong Bikang).

Tabel 5. Deteksi logam berat dalam air di lokasi sampling musim kemarau

\begin{tabular}{|c|c|c|c|c|}
\hline \multirow{2}{*}{ Area } & \multirow{2}{*}{ Titik Sampling } & \multirow{2}{*}{ Unit } & \multicolumn{2}{|c|}{$\begin{array}{l}\text { Konsentrasi Logam Berat dalam Air } \\
\text { (mg//L) }\end{array}$} \\
\hline & & & As & $\mathrm{Hg}$ \\
\hline \multirow{6}{*}{ Site I } & Air Baku PLN Merawang & $\mathrm{mg} / \mathrm{L}$ & $0.004 \pm 0.000$ & $0.002 \pm 0.000$ \\
\hline & Air Baku PDAM - Merawang & $\mathrm{mg} / \mathrm{L}$ & $<0.003 \pm 0.000$ & $0.001 \pm 0.000$ \\
\hline & Air Baku PDAM - Pemali & $\mathrm{mg} / \mathrm{L}$ & $<0.003 \pm 0.000$ & $0.001 \pm 0.000$ \\
\hline & Open Pit Pemali TB Timah & $\mathrm{mg} / \mathrm{L}$ & $<0.003 \pm 0.000$ & $0.001 \pm 0.000$ \\
\hline & Air Jangkang ex TB 1.9 & $\mathrm{mg} / \mathrm{L}$ & $<0.003 \pm 0.000$ & $0.004 \pm 0.001$ \\
\hline & Kolong Kenanga & $\mathrm{mg} / \mathrm{L}$ & $0.006 \pm 0.000$ & $0.002 \pm 0.000$ \\
\hline \multirow{2}{*}{ Site II } & K. Ret. Kacang Pedang Hilir I & $\mathrm{mg} / \mathrm{L}$ & $<0.003 \pm 0.000$ & $0.001 \pm 0.000$ \\
\hline & K. Ret. Kacang Pedang Hilir II & $\mathrm{mg} / \mathrm{L}$ & $<0.003 \pm 0.000$ & $0.001 \pm 0.000$ \\
\hline \multirow{3}{*}{ Site III } & KolongBikang & $\mathrm{mg} / \mathrm{L}$ & $<0.003 \pm 0.000$ & $0.002 \pm 0.000$ \\
\hline & Kolong Parit TigaToboali & $\mathrm{mg} / \mathrm{L}$ & $0.009 \pm 0.000$ & $0.001 \pm 0.000$ \\
\hline & KolongAcamRindik & $\mathrm{mg} / \mathrm{L}$ & $<0.003 \pm 0.000$ & $0.001 \pm 0.000$ \\
\hline \multicolumn{2}{|c|}{ MDL (Method Detection Limit) } & $\mathrm{mg} / \mathrm{L}$ & 0,003 & 0,001 \\
\hline \multicolumn{2}{|c|}{ PP RI no. 82 tahun 2001 untukKelas I } & $\mathrm{mg} / \mathrm{L}$ & 0,05 & 0,001 \\
\hline
\end{tabular}


Berdasarkan analisa konsentrasi As dan $\mathrm{Hg}$ dalam sedimen di musim kemarau menunjukkan hasil yang cukup tinggi di beberapa lokasi, hingga melebihi baku mutu, sebagaimana tercantum dalam Tabel 6 .

Tingginya nilai konsentrasi As dan $\mathrm{Hg}$ dalam sedimen sebanding dengan tingginya konsentrasi logam-logam tersebut dalam airnya. Berbeda dengan Kolong Kenanga, dimana konsentrasi As di dalam air lebih tinggi dari sedimen. Hal ini dimungkinkan kelarutan As selain dipengaruhi nilai $\mathrm{pH}$ juga dipengaruhi temperatur air. Semakin tinggi temperatur air maka air mempunyai kemampuan melarutkan mineral atau logam dari sedimennya, sehingga konsentrasi logam dalam airnya lebih tinggi, sebagaimana ditunjukkan dalam gambar 5.

Tabel 6. Deteksi logam berat dalam sedimen di lokasi sampling musim kemarau

\begin{tabular}{|c|c|c|c|c|}
\hline \multirow[t]{2}{*}{ Area } & \multirow[t]{2}{*}{ Titik Sampling } & \multirow[t]{2}{*}{ Unit } & \multicolumn{2}{|c|}{$\begin{array}{l}\text { Konsentrasi Logam Berat dalam Sedimen } \\
\qquad(\mathrm{mg} / \mathrm{kg} \text { beratkering)* }\end{array}$} \\
\hline & & & As & $\mathrm{Hg}$ \\
\hline \multirow{6}{*}{ Site I } & Air baku PLN - Merawang & $\mathrm{mg} / \mathrm{L}$ & $99,686 \pm 0,084$ & $0,679 \pm 0,001$ \\
\hline & Air bakuPDAM-Merawang & $\mathrm{mg} / \mathrm{L}$ & $76,797 \pm 3,865$ & $0,196 \pm 0,038$ \\
\hline & Air bakuPDAM - Pemali & $\mathrm{mg} / \mathrm{L}$ & $40,930 \pm 0,274$ & $0,513 \pm 0,153$ \\
\hline & OpenPitPemali TB Timah & $\mathrm{mg} / \mathrm{L}$ & $37,531 \pm 1,865$ & $0,431 \pm 0,160$ \\
\hline & Air Jangkang Ex TB 1.9 & $\mathrm{mg} / \mathrm{L}$ & $19,752 \pm 0,767$ & $0,249 \pm 0,030$ \\
\hline & Kolong Kenanga & $\mathrm{mg} / \mathrm{L}$ & $17,037 \pm 0,734$ & $0,658 \pm 0,070$ \\
\hline \multirow{2}{*}{ Site II } & K.Ret. Kacang Pedang Hilir I & $\mathrm{mg} / \mathrm{L}$ & $4,109 \pm 0,198$ & $0,355 \pm 0,185$ \\
\hline & K.Ret.Kacang PedangHilir II & $\mathrm{mg} / \mathrm{L}$ & $8,266 \pm 0,085$ & $0,276 \pm 0,029$ \\
\hline \multirow{3}{*}{ Site III } & KolongBikang & $\mathrm{mg} / \mathrm{L}$ & $3,180 \pm 0,172$ & $0,611 \pm 0,031$ \\
\hline & KolongParitTigaToboali & $\mathrm{mg} / \mathrm{L}$ & $43,171 \pm 3,935$ & $0,169 \pm 0,001$ \\
\hline & KolongAcamRindik & $\mathrm{mg} / \mathrm{L}$ & $10,159 \pm 1.250$ & $0,444 \pm 0,077$ \\
\hline \multicolumn{2}{|c|}{ MDL(Method Detection Limit) } & $\mathrm{mg} / \mathrm{L}$ & 0,003 & 0,001 \\
\hline \multicolumn{2}{|c|}{ Baku MutuSedimen WAC 173-204-320 } & $\mathrm{mg} / \mathrm{L}$ & 57,00 & 0,41 \\
\hline
\end{tabular}

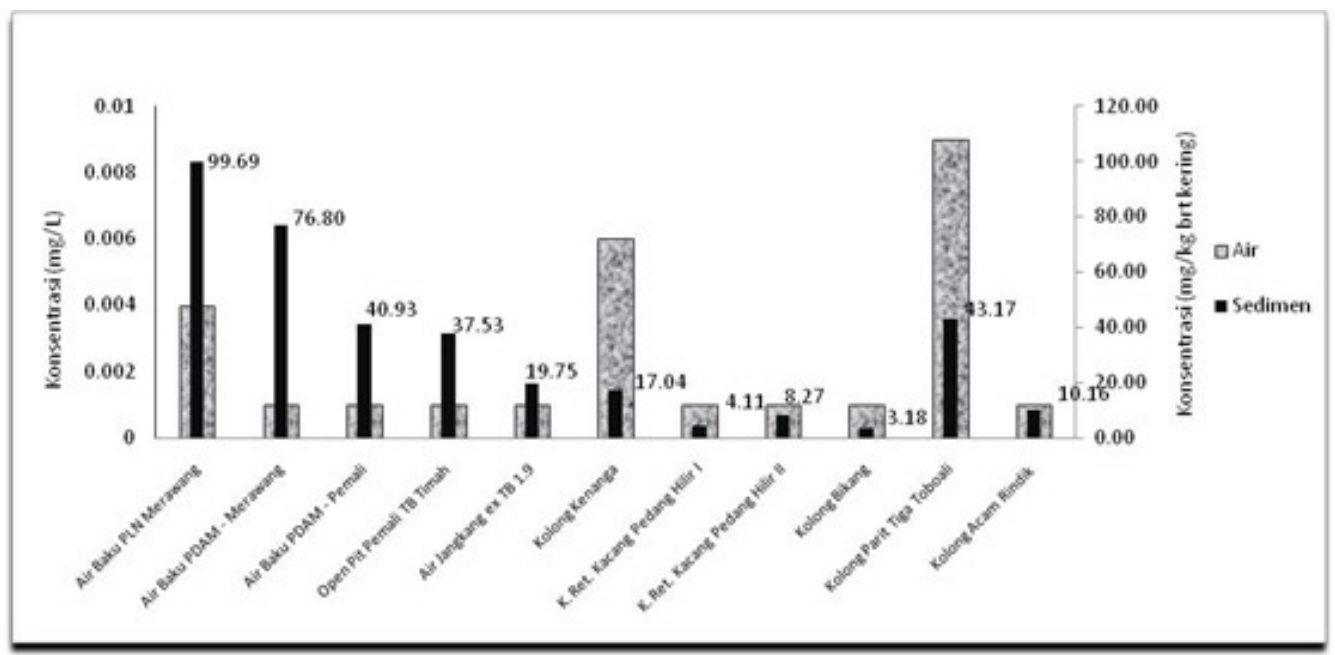

Gambar 5. Konsentrasi Logam Arsen di Beberapa Lokasi Sampling Musim Kemarau. 


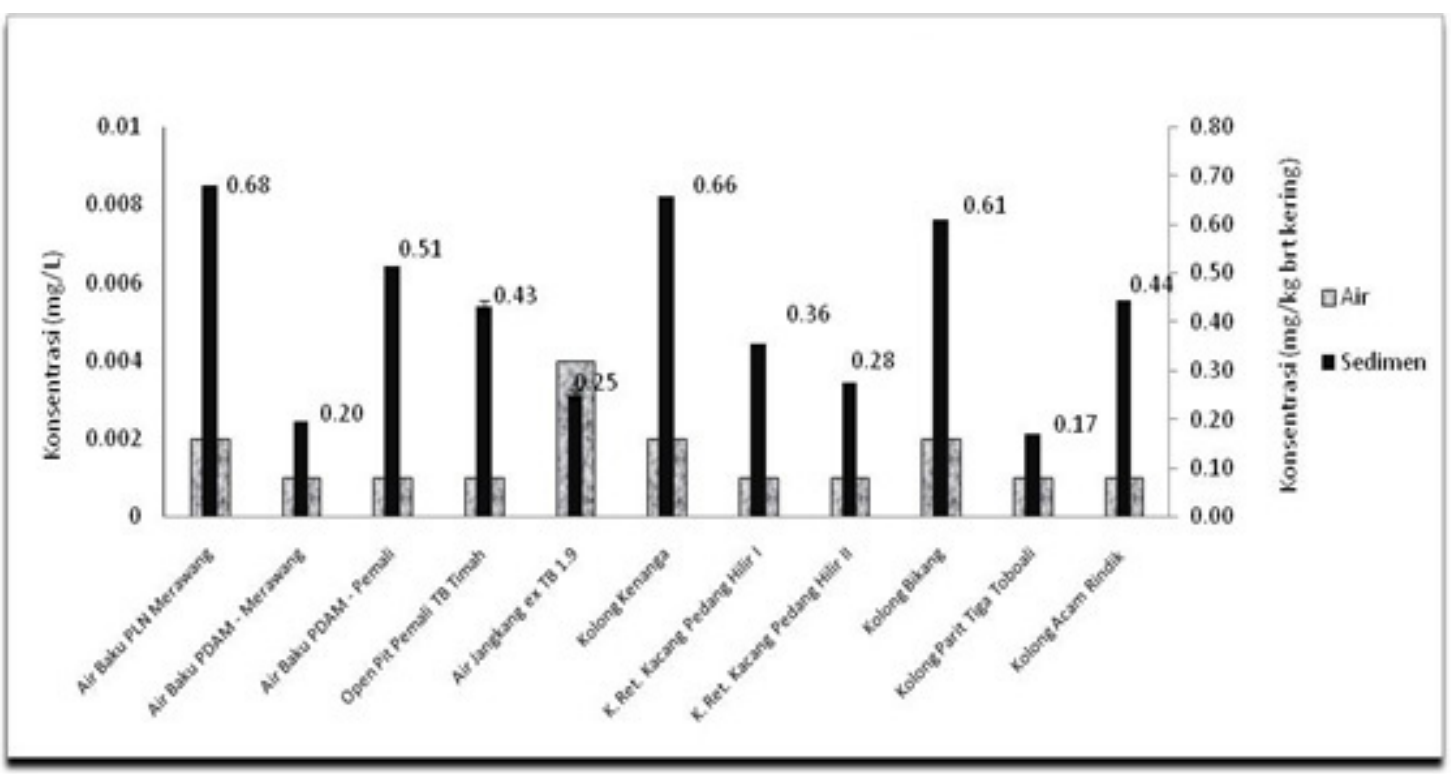

Gambar 6. Konsentrasi Logam Merkuri di Beberapa Lokasi Sampling Musim Kemarau.

Untuk keseluruhan lokasi, konsentrasi logam berat dalam sedimen lebih besar dibandingkan dalam air. Hal ini dapat dijelaskan, karena logam berat mempunyai kecenderungan terakumulasi dalam sedimen di mana memungkinkan untuk terlepas, melalui rantai makanan ${ }^{9)}$. Logam berat yang berhasil memasuki rantai makanan akan terakumulasi di rantai terakhir.

Dalam sedimen di perairan tercemar, sebagian besar logam berat berasosiasi dengan materi organik (asam humus, koloid), fraksi sedimen halus (tanah liat, silt dan pasir halus) dan Fe/Mn hidroksida atau mengendap sebagai hidroksida, sulfida atau karbonat ${ }^{10)}$. Interaksi antar logam dan materi organik pada sedimen telah banyak ditemukan ${ }^{10}$. Untuk menghindari gangguan akibat interaksi tersebut, dalam perlakuan preparasi sampel perlu dilakukan digestion dengan aqua regia, di mana diharapkan hanya logam berat yang akan terdestruksi dan dianalisa, serta mampu merepresentasikan hasil dari lokasi sampling.
Karakteristik logam berat dalam sedimen cukup bervariasi di setiap lokasi sampling di mana hal ini mungkin dipengaruhi oleh faktor geologi pembentukan masing-masing lokasi. Besar kecilnya nilai konsentrasi logam yang terdapat dalam air baku PDAM, yang merupakan kolong alami, dipengaruhi oleh lingkungan geografis sekitar lokasi sampling 11).

Kolong tua mungkin akan lebih baik digunakan sebagai sumber air baku PDAM mengingat kondisi pH airnya yang lebih netral ${ }^{12)}$.

\section{KESIMPULAN}

Berdasarkan pengukuran konsentrasi As dan $\mathrm{Hg}$ dalam air dan sedimen di kolong bekas penambangan timah di Propinsi Bangka Belitung, ternyata konsentrasi arsen dalam air memenuhi baku mutu Peraturan Pemerintah No.82 tahun 2001 untuk air baku air minum, sedangkan konsentrasi merkuri di beberapa lokasi sampling mempunyai nilai yang melebihi baku mutu tersebut.Hasil penentuan 
logam arsen dan merkuri dalam sedimen di beberapa lokasi sampling menunjukkan nilai konsentrasi di atas baku mutu sedimen WAC 173-204-320, terutama di Site I. Sumber air baku PDAM sebaiknya diambil dari kolong tua (berusia di atas 40 tahun) mengingat kondisi $\mathrm{pH}$ airnya yang lebih netral. Hasil pengukuran logam arsen dan merkuri dalam air kolong yang memenuhi baku mutu air, dapat menjadi salah satu dasar dalam pemilihan lokasi PDAM sebagai sumber air baku air minum.

\section{SARAN}

Lokasi sampling yang mempunyai nilai konsentrasi logam berat dalam air yang melebihi baku mutu air baku air minum sebaiknya tidak digunakan sebagai sumber air baku air minum.

\section{UCAPAN TERIMA KASIH}

Kegiatan ini didanai melalui kerjasama Pusat Penelitian Kimia LIPI dengan International Environment Research Center - Gwangju Institute, Korea. Terima kasih disampaikan kepada Pemerintah Daerah Propinsi Bangka Belitung dan PT Timah (Tbk) atas perijinan dan kerjasamanya selama studi berlangsung.

\section{DAFTAR PUSTAKA}

1. Karadede, H -Akin, and Erhan Ünlü. 2007. Heavy Metals Concentrations in Water, Sediment, Fish and Some Benthic Organisms from Tigris River, Turkey. Environ Monit Assess. 131: 323-337.

2. Williams, M., F. Fordyce, A. Paijitprapapon, and P. Charoenchaisri. 1996. Arsenic Contamination in Surface
Drainage and Groundwater in part of the Southeast Asian Tin Belt. Nakhon Si Thammarat Province, southern Thailand. Environmental Geology 27 : 16-33.

3. Merck. The Merck Index. $10^{\text {th }}$ ed., ISBN 0-911910-27-1. 1983.

4. International standard, ISO 56672:1991 (E)

5. APHA-AWWA-WEF.part.No. 3114, Standard method edisi 21, 2005

6. Yimin.W, Y., Peng Chen, Ruina Cui, Wantong Si, Yingmei Zhang, and WeihongJi. "Heavy Metal Concentrations in Water, Sediment, and Tissues of Two Fish Species (Triplohysapappenheimi, Gobiohwanghensis) from the Lanzhou Section of the Yellow River, China." Environ Monit Assess. DOI 10.1007/ s10661-009-0929-2.

7. Sawyer, Clair N., et al. 2003. Chemistry for Environmental and Engineering Science. $5^{\text {th }}$.

8. Smedley, P. L.; Kinniburgh, D. G. A . 2002. Review of the Source,Behavior and Distribution of Arsenite in Natural Waters". Appl.Geochem. . 17, 517.

9. Nabawi, A., B. Heinzow, and H. Kruse. "As, $\mathrm{Cd}, \mathrm{Cu}, \mathrm{Pb}, \mathrm{Hg}$, and $\mathrm{Zn}$ in Fish from Alexandria Region, Egypt 1987. "Bulletin of Environmental Contamination and Toxicology 39 : 889-897.

10. Jain, C. K., D.C. Singhal, and M. K. Sharma. 2005. Metal Pollution Assessment of Sediment and Water in The River Hindon, India. Environmental Monitoring and Assessment 105 : 193-207.

11. Karadede, H. and ErhanÜnlü. 2000. Concentrations of Some Heavy 
Metals in Water, Sediment and Fish Species from the Atatürk Dam Lake (Euphrates), Turkey. Chemosphere. Vol 41 issue 9 Nov.

12. Rahayuningwulan, D. Ardeniswan, H.E.Putra, dan Y. Sudiyani, 2009.
Determinasi LogamBeratdalam Air danSedimen di KolamBekas Tambang Timah (Air Kolong) di Propinsi BangkaBelitung, Indonesia. Lingkungan Tropis. ISSN no.1978-2713, p 543-552. 